\title{
Thermal seasons in Warsaw during the period 1961-2013
}

\section{Abstract}

This study determines the approximate duration of the thermal seasons in Warsaw, and investigates their long-term variability. The measurement data come from the Ursynów meteorological station at the Warsaw University of Life Sciences (WULS) $\left(\lambda_{E} 21^{\circ} 02^{\prime} 52^{\prime \prime}, \varphi_{N} 52^{\circ} 09^{\prime} 38^{\prime \prime}, 102.5\right.$ $\mathrm{m}$ a.s.I.), situated in the south of Warsaw, and comprise mean diurnal air temperatures for the years 1961-2013. In order to identify thermal seasons, the method of five-day rolling averages was applied, which revealed a substantial year-by-year variability. The achieved results were close to those found by other methods for stations situated within the same climatic region. Over the analysed period, winters and springs have become shorter, whereas the other two seasons have become longer. Nevertheless, the positive trend was only statistically significant for thermal summers. The increasing length of the thermal summer in Warsaw Ursynów may be due to the influence of urban heat islands in built-up areas.

Keywords

Air temperature $\cdot$ thermal season $\cdot$ city $\cdot$ Warsaw

(C) University of Warsaw - Faculty of Geography and Regional Studies

\author{
Grzegorz Majewski \\ Wiesława Przewoźniczuk \\ Division of Meteorology and Climatology \\ Faculty of Civil and Environmental Engineering \\ Warsaw University of Life Sciences \\ e-mail: grzegorz_majewski@sggw.pl \\ e-mail: wieslawa_przewozniczuk@sggw.p \\ Received: 19 February 2014 \\ Accepted: 26 June 2014
}

Introduction

Differences in the duration of thermal seasons and in their beginning and end dates reflect both the 'transient' characteristics of our climate, and changes (fluctuations) in the climate. The common division of the year into seasons according to calendar months, or into astronomical seasons, does not fully consider the specificity of individual seasons in our climatic conditions. The division of the year into periods according to their thermal properties has long been established as being more appropriate. The idea of thermal seasons was originally introduced at the beginning of the $20^{\text {th }}$ century (Merecki 1915; Romer 1938). The scientists observed that six seasons could be identified in Poland using thermal criteria. The occurrence of two additional seasons, early spring and early winter, was believed to be a peculiarity of the regional climate. Some other researchers have taken a phenological point of view and approved the division of the year into eight thermal seasons (Wiszniewski 1960; Makowiec 1983), whereas Hess (1965) identified as many as 10 seasons for mountainous areas.

Literary sources offer different methods for determining the thermal seasons. The widely accepted and most frequently used method is based on the identification of the time when the longterm monthly mean air temperature passes the thermal threshold values of $0^{\circ} \mathrm{C}, 5{ }^{\circ} \mathrm{C}$ and $15^{\circ} \mathrm{C}$. This can be achieved with calculations, the formulas for which were developed by Gumiński (1948), and using graphics with the assumption that the monthly mean air temperature is similar to the diurnal mean of the $15^{\text {th }}$ day of the month and that each month is 30 days long (Hess 1965).

On the other hand, Makowiec (1983) proposed a method which involves calculating cumulative series of deviations of the mean diurnal values of air temperature from threshold values.
However, the point at which the long-term mean diurnal value of air temperature passes specific thermal thresholds (Stopa 1968) is regarded as the most precise way to determine thermal seasons. It turns out that there is a considerable difference between the beginning and end dates of thermal seasons determined using monthly and diurnal mean values of air temperature (Piotrowicz 2002).

The determination of the beginning of a thermal winter and its duration is the most challenging, because winter is characterised by the greatest variability of climatic properties of all the seasons, which is quite the opposite for summer (Hess 1974; Trepińska 1997).

When determining thermal seasons on the basis of diurnal mean values of air temperature, the problem arises of temperature values continually exceeding the thermal thresholds. Some researchers solve this problem by equalising the courses of mean diurnal air temperature by means of algebraic polynomials, trigonometric series, or a low-pass symmetrical filter (Nowosad \& Filipiuk 1998). According to Piotrowicz (2002), such courses should be considered a characteristic property of our climate, rather than smoothed out. Szyga-Pluta (2011) proposes the calculation of the value of mean air temperature in thermally unstable periods as a criterion for classifying the period as belonging to the appropriate season.

In her study on the determination of thermal winters, Piotrowicz (2002) considered and compared five methods, concluding that none of them was fully objective and that the obtained results revealed substantial differences. According to Piotrowicz, the method based on the calculation of five-day rolling averages was the least biased of the analysed methods. 


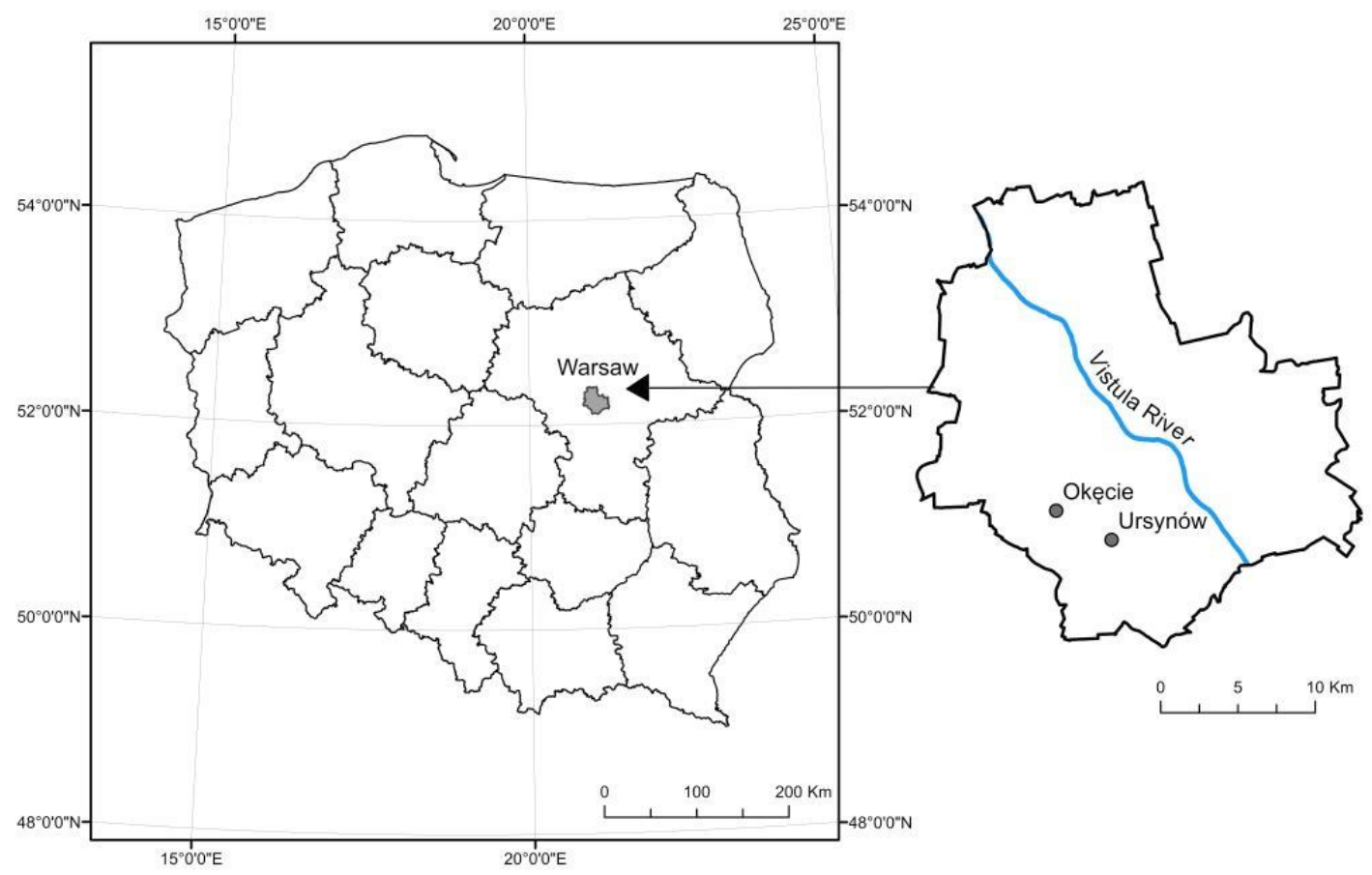

Figure 1. Location of meteorological stations in Warsaw, Poland

The aim of the current study was to investigate how the timing and duration of thermal seasons changed over the 50 -year period of air temperature measurements at the WULS Ursynów meteorological station, located in Ursynów, the southernmost district of Warsaw.

\section{Materials and method}

The measurement data used in this study were sourced from the WULS Ursynów meteorological station $\left(\lambda_{E} 21^{\circ} 0252^{\prime \prime}, \varphi_{N}\right.$ $52^{\circ} 09^{\prime} 38^{\prime \prime}, 102.5 \mathrm{~m}$ a.s.I.), located in the south of Warsaw, operated by the WULS Division of Meteorology and Climatology (Fig. 1).

The station is situated in an area that was used as agricultural land until 1975. From 1975 to 2002 a complex of residential estates was built in the vicinity. Furthermore, from 2001 to 2008 the area of the WULS campus, where the station is now located, was substantially developed. The influence of this change of land use on the local climate in Ursynów has been addressed by Rozbicki \& Gołaszewski (2005), Gołaszewski et al. (2007), and Majewski et al. $(2012,2014)$.

The source material for the determination of thermal seasons comprised mean diurnal values of air temperature for the period 1961-2013, i.e. 52 winters and 52 of each of the other seasons of the year.

In order to identify the thermal seasons, the authors of this study applied one of the methods used by Piotrowicz (2002) to determine thermal winters. This method involved the calculation of five-day rolling averages, equalising the course of the diurnal mean of the air temperature by eliminating a series of winter days, lasting from one to a few days, that appear at the end of October, in November, March or April, but without overlooking longer fluctuations (Piotrowicz 2002). The year was divided into six seasons, after Romer (1949), on the basis of the following thermal thresholds: $0.0^{\circ} \mathrm{C}, 5.0{ }^{\circ} \mathrm{C}$ and $15{ }^{\circ} \mathrm{C}$. The first day that the fiveday rolling average value passed the relevant thermal threshold was considered the start date of the season, whereas the last day preceding an increase of the five-day rolling average above the specific threshold was accepted as the end of the given season.

As the rolling average is assigned to the middle day of a five-day series, whenever its value decreased below the relevant thermal threshold, the date had to be moved by one or two days, as appropriate. Therefore, the use of this method was quite laborious.

\section{Results and discussion}

Basic monthly and annual statistics of air temperature values provide an overview of the prevalent thermal conditions during the period 1961-2012 (Fig. 2). In the analysed period, the mean annual air temperature at the WULS Ursynów station was 8.4 ${ }^{\circ} \mathrm{C}$ and ranged from $6.5^{\circ} \mathrm{C}$ (in 1965) to $10.1^{\circ} \mathrm{C}$ (in 2000), with a mean monthly maximum in July of $19^{\circ} \mathrm{C}$, and the mean monthly minimum in January reaching $-2.4^{\circ} \mathrm{C}$. All analysed monthly and annual periods were characterised by a temporal variability of air temperature. Cold months revealed a greater variability as compared with warm and transitional months. The highest values of standard deviation were observed in January and February (3.6 ${ }^{\circ} \mathrm{C}$ and $3.4{ }^{\circ} \mathrm{C}$, respectively), whereas the lowest were observed in December and March $\left(2.8{ }^{\circ} \mathrm{C}\right.$ and $2.5^{\circ} \mathrm{C}$, respectively). In the analysed period, the highest monthly value of air temperature was recorded in July $2006\left(23.8^{\circ} \mathrm{C}\right)$ and the coldest month was January 1963 , when the mean air temperature did not exceed $-12.4^{\circ} \mathrm{C}$.

For the purpose of determining the air temperature tendency for individual months during the period 1961-2013, the linear trend equations were solved and the values of the trend coefficients were determined (Tab. 1). An analysis of the trends revealed that monthly mean values of air temperature in January, March, April, May, July and August, as well as the annual mean, were characterised by a statistically significant change in the form 
Table 1. Linear trend coefficients and the rate of increase of air temperature in individual months in Warsaw during the period 1961-2012 (WULS Ursynów)

\begin{tabular}{|c|c|c|}
\hline Month & Trend & $\begin{array}{c}\text { Temperature increase } \\
\text { over the 52-year-long } \\
\text { period }\end{array}$ \\
\hline I & $0.072^{*}$ & 3.7 \\
\hline II & 0.045 & 2.3 \\
\hline III & $0.057^{*}$ & 3.0 \\
\hline IV & $0.051^{* *}$ & 2.6 \\
\hline V & $0.044^{* *}$ & 2.3 \\
\hline VI & 0.024 & 1.3 \\
\hline VII & $0.061^{* *}$ & 3.2 \\
\hline VIII & $0.054^{* *}$ & 2.8 \\
\hline IX & 0.021 & 1.1 \\
\hline X & 0.012 & 0.6 \\
\hline XI & 0.018 & 0.9 \\
\hline XII & 0.036 & 1.9 \\
\hline I-XII & $0.041^{* *}$ & 2.1 \\
\hline
\end{tabular}

*-statistical significance level 5\%

**-statistical significance level $1 \%$

Table 2. Approximate start and end dates of thermal seasons during the period 1961-2012/13 in Warsaw (WULS Ursynów)

\begin{tabular}{|c|c|c|c|c|}
\hline Season & $\begin{array}{c}\text { Start } \\
\text { date }\end{array}$ & $\begin{array}{c}\text { End } \\
\text { date }\end{array}$ & $\begin{array}{c}\text { Length } \\
\text { (days) }\end{array}$ & $\begin{array}{c}\text { Mean air } \\
\text { temperature }\left[{ }^{\circ} \mathrm{C}\right]\end{array}$ \\
\hline Winter & $8 \mathrm{Dec}$ & $27 \mathrm{Feb}$ & 65 & -1.6 \\
\hline Early spring & $28 \mathrm{Feb}$ & $27 \mathrm{Mar}$ & 29 & 2.2 \\
\hline Spring & $28 \mathrm{Mar}$ & $25 \mathrm{May}$ & 57 & 10.6 \\
\hline Summer & $26 \mathrm{May}$ & $9 \mathrm{Sep}$ & 110 & 17.8 \\
\hline Autumn & $10 \mathrm{Sep}$ & $9 \mathrm{Nov}$ & 56 & 9.6 \\
\hline Early winter & $10 \mathrm{Nov}$ & $7 \mathrm{Dec}$ & 42 & 2.1 \\
\hline
\end{tabular}

of a positive trend. In the other months, there were only (positive) tendencies, as the statistics did not reveal significant changes. The month with the highest rate of increase in mean temperature was January $\left(0.072{ }^{\circ} \mathrm{C} \mathrm{yr}^{-1}\right)$. During the period $1961-2013$, the value of the linear trend coefficient was $0.041{ }^{\circ} \mathrm{C} \mathrm{yr}^{-1}$, which translates into an increase of the annual mean air temperature in Warsaw of approx. $2.1^{\circ} \mathrm{C}$ (Tab. 1).

Using the five-day rolling average method, the results of calculating the duration of thermal seasons and their beginning and end dates were equalised for the entire period 1961-2013 (Fig. 3 and Tab. 2).

The approximate dates of the beginning and end of the thermal seasons in Warsaw (obtained by means of the five-day rolling average method) are very similar to those determined by Kossowska-Cezak (2005), despite the fact that the author used a different approach and analysed a much longer period of 70 years. The differences between the obtained results do not exceed 6 days, except for the early spring season, where the difference is 23 days. Yet the start date of early spring as established by the authors of this study $-28^{\text {th }}$ February - seems more likely, as

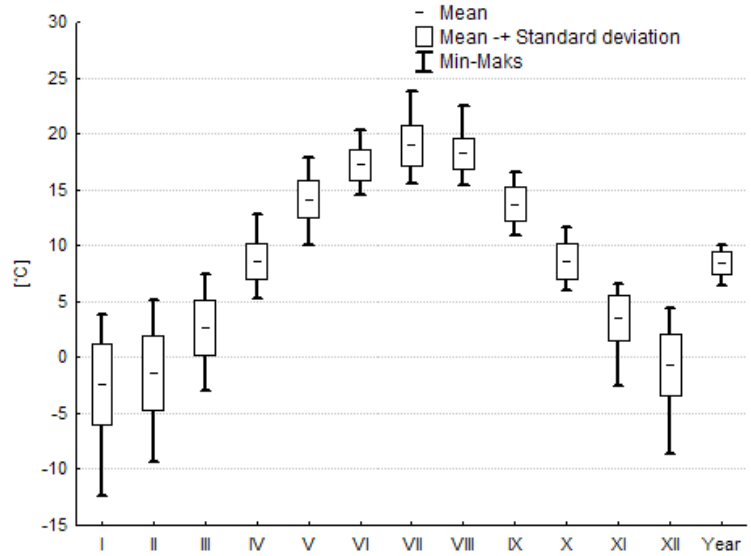

Figure 2. Basic statistics of monthly and annual values of air temperature in Warsaw during the period 1961-2012 (WULS Ursynów)

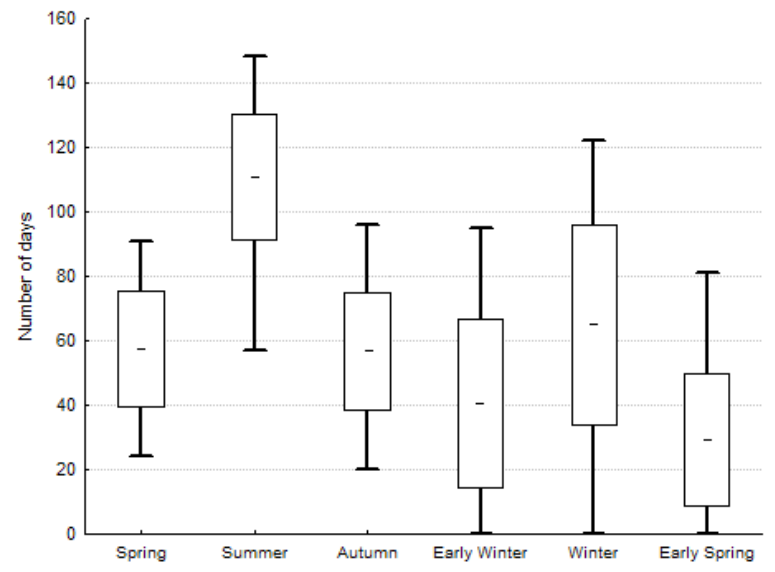

Figure 3. Mean and extreme lengths of thermal seasons in Warsaw during the period 1961-2012/13 (WULS Ursynów)

it is the same as obtained for the city of Łódź by Degirmendžić \& Kożuchowski (2004), who used the Huculak and Makowiec method. The end of the thermal winter and the beginning of the early spring period in other regions of Poland also falls in the last days of February, namely on the $26^{\text {th }}$ in Poznan (Szyga-Pluta 2011), the $19^{\text {th }}$ in Zamość (Samborski \& Bednarczuk 2009), the 25 th in Kraków (Piotrowicz 2000) and the $26^{\text {th }}$ in Western Pomerania (Franków 2008), even though the different authors used different calculation methods and reference periods. The approximated beginning of the other seasons, as established by the authors for Warsaw during the period 1961-2013, are most similar to those obtained in Łódź by Degirmendžić \& Kożuchowski (2004). The differences are merely 3 days for spring and autumn, 4 days for winter and 5 days for early winter.

The average duration of winter, determined using the fiveday rolling average method, was 65 days, with variability ranging from 0 to 122 days. The last winter of 2012/2013 turned out to be the longest and did not end until the $2^{\text {nd }}$ day of April. On the other hand, in the 1988/1989 season there was no thermal winter at all, according to the applied methodology. The studies of KossowskaCezak (2005), which used data from the Okęcie meteorological station in Warsaw, also revealed the absence of a thermal winter in the 1988/1989 season. Despite the different location 


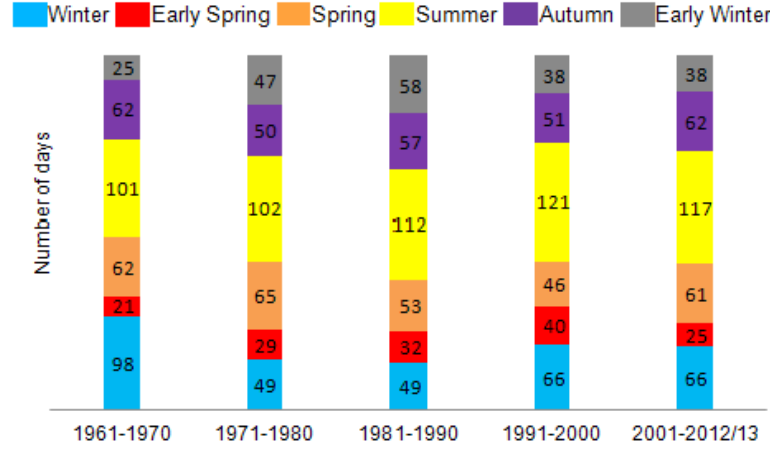

Figure 4. Average duration of thermal seasons for individual decades during the period 1961-2012/13 in Warsaw (WULS Ursynów)

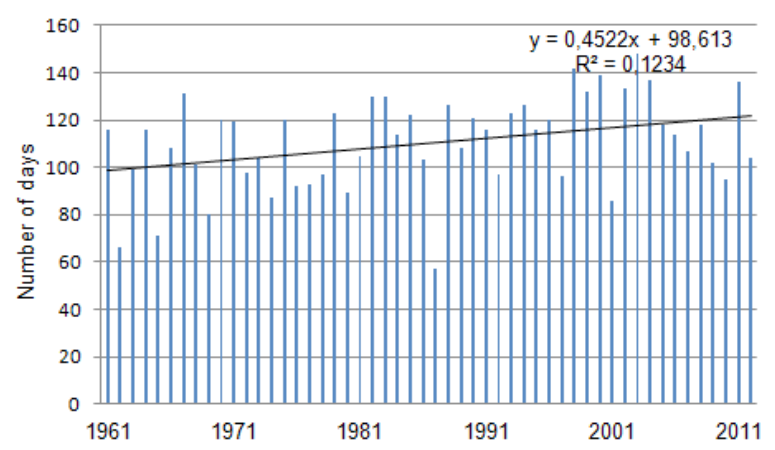

Figure 5. Average duration of thermal summer in Warsaw during the period 1961-2012 (WULS Ursynów)

Table 3. Trends in the duration of thermal seasons in Warsaw during the period 1961-2012/13 (WULS Ursynów)

\begin{tabular}{|c|c|c|c|c|c|}
\hline Spring & Summer & Autumn & $\begin{array}{c}\text { Early } \\
\text { winter }\end{array}$ & Winter & $\begin{array}{c}\text { Early } \\
\text { spring }\end{array}$ \\
\hline-0.14 & $0.45^{*}$ & 0.09 & 0.06 & -0.51 & 0.17 \\
\hline
\end{tabular}

*- coefficient significant at the level of 0.05

of measurement points, the different periods of analysis and approaches, both studies share certain regularities: the longest winters $(100+$ days) occurred in the 1960s and were absent in the 1970s and 1980s. In Warsaw Ursynów, a winter lasting longer than 100 days occurred as late as 1996 and then twice in the first decade of the $21^{\text {st }}$ century. The mean standard deviation for the length of winter was 31 days, both in Ursynów and Okęcie (Kossowska-Cezak 2005).

Theoretically, one should not compare the results of studies conducted in different periods and using different methods. However, the authors of this study believe that, since both measurement stations are situated in the same climatic region, the results should not be significantly different. The average lengths of early spring, spring, autumn and early winter determined for Warsaw Ursynów hardly differ from those calculated for Warsaw Okęcie, ranging from 1 day in spring to 5 days in early spring (Kossowska-Cezak 2005). The differences between Warsaw Ursynów and Łódź also fall within 2-6 days. As far as the duration of winter and summer is concerned, the differences are noticeably greater: 10 days and 11 days, respectively. However, in Warsaw Ursynów winter was the shortest and summer the longest of all the compared stations.
Considering the argument put forward by some climatologists that winters are becoming shorter and early springs are becoming longer (Samborski \& Bednarczuk 2009; Kossowska-Cezak 2005; Skowera \& Kopec 2000), the average duration of thermal seasons in the individual decades was analysed (Fig. 4). Indeed, this tendency can be observed until the end of the previous century. Skowera and Kopeć (2000) explain this observation by referring to an increase in the advection of air masses from the west in the last 20 years of the $20^{\text {th }}$ century. However, developments observed in the first decade of the $21^{\text {st }}$ century and at the beginning of the second decade have not confirmed this tendency, although the thermal summers have become longer.

The authors analysed the trends in the duration of thermal seasons from 1961 to $2012 / 13$. The values of the trends show a tendency towards shortened winters and springs and a corresponding extension of the other seasons (Tab. 3). However, only the positive trend of thermal summers proved statistically significant, at a level of $\alpha=0.05$ (Fig. 5). Accordingly, summer was extended by approx. 23 days when comparing the data for the first and last days of the reference period. In the authors' opinion, this result is an effect of the influence of the urban heat island of Warsaw on the measurements of air temperature. This may affect a number of other meteorological stations and sites, once situated on the outskirts and now surrounded by the infrastructure of developing cities, which change the vicinity of measurement points.

The comparison of changes occurring in the air temperature at the WULS Ursynów station, carried out by Majewski, Odorowska \& Rozbicka (2012), Majewski, Przewoźniczuk \& Kleniewska (2014), and Rozbicki, Gołaszewski \& Łykowski (2005), demonstrated that as the surroundings of the station became increasingly built up after 1960, the temperature of the air gradually increased, as compared with corresponding measurements from the Okęcie station, where no substantial changes in the surroundings took place (Fig. 1).

The area in which the Ursynów station is situated has been extensively transformed over the years. In order to describe the changes in the station's surroundings, a map illustrating urban development for consecutive decades of the past 50 years was used (Fig. 6). The influence on air temperature is visible in the mean monthly and annual temperature differences between the Ursynów station and the suburban Okęcie station (Tab. 4). In the 1960s the surroundings of the Ursynów-SGGW station comprised agricultural land. No temperature differences between the stations were observed for this decade (Tab. 4). After 1970, housing in the Ursynów district was expanded on a large-scale, and after 2000 the WULS Campus underwent intensive construction in the direct surroundings of the station. As a result of this vital urban development, the temperature difference between the Ursynów and Okęcie stations rose by $0.2^{\circ} \mathrm{C}$ on average per decade.

\section{Conclusions}

1. During the analysed period, it was observed that winter and spring have tended to become shorter, whereas the other seasons of the year have become longer. Nevertheless, only the positive trend of thermal summer was found to be statistically significant. The increasing length of thermal summer in Warsaw Ursynów is an effect of the influence of the urban heat island, as the measurement station is located in a built-up area.

2. The decrease in the length of winter was observable until the 1990s. In the last two decades analysed by the authors, the phenomenon halted. The longest winters (lasting for 98 days on average) occurred between the years 1961-1970, whereas the shortest occurred between 1998-1990. The longest summers (lasting for 121 days on average) occurred 


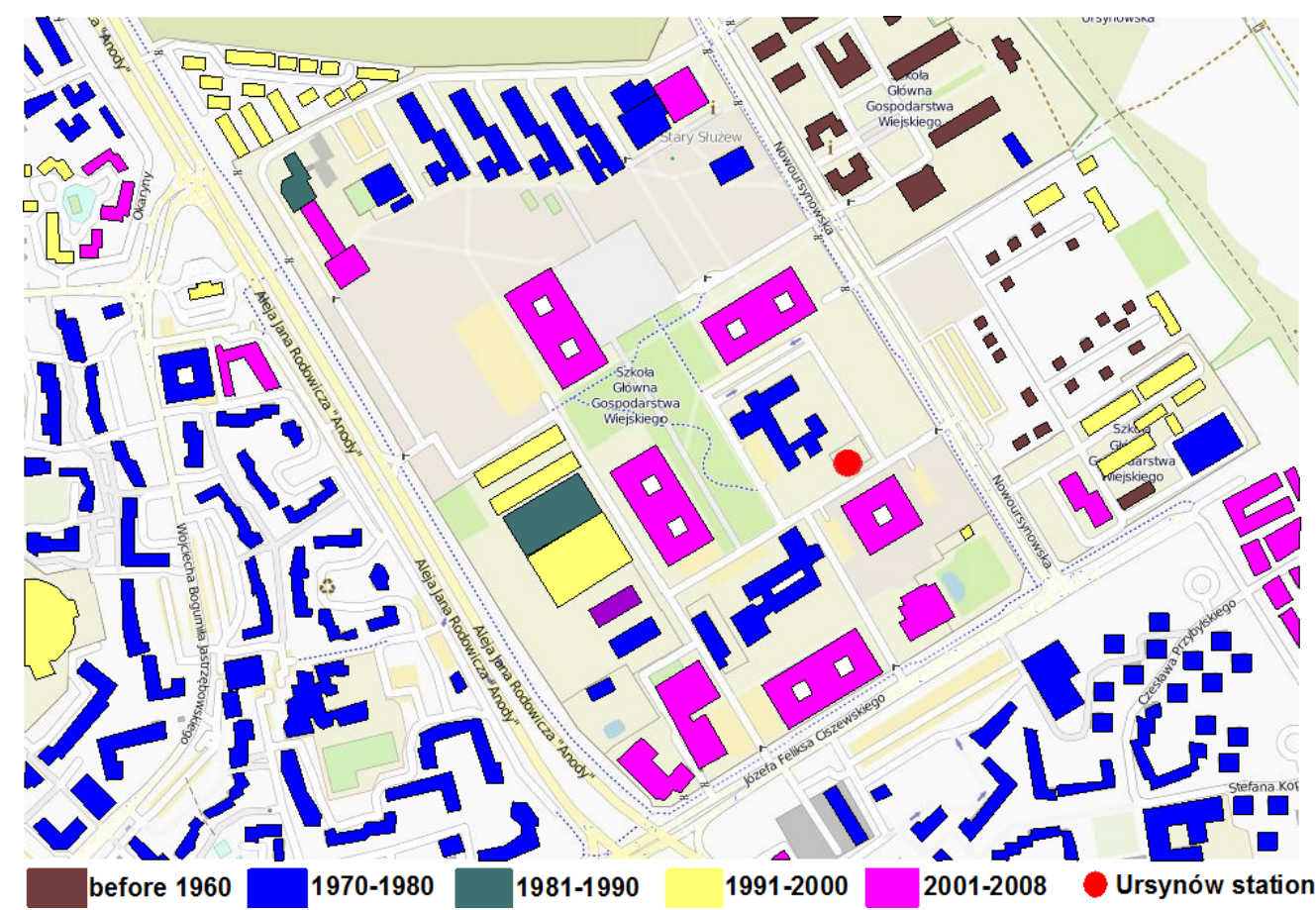

Figure 6. Changes to built-up areas in the surroundings of the Ursynów station from 1960 to 2008

Table 4. Monthly mean and yearly mean air temperature differences between the Ursynów and Okęcie stations during the period 1960-2008. Note. The data are from, (after Majewski et al. 2012)

\begin{tabular}{|c|c|c|c|c|c|c|c|c|c|c|c|c|c|}
\hline Period & I & II & III & IV & V & VI & VII & VIII & IX & X & XI & XII & Year \\
\hline $1960-1970$ & 0.1 & 0.0 & 0.0 & -0.2 & 0.0 & -0.1 & 0.2 & -0.2 & 0.0 & 0.0 & 0.0 & 0.0 & 0.0 \\
\hline $1971-1980$ & 0.0 & 0.1 & 0.4 & 0.1 & 0.3 & 0.2 & 0.3 & 0.1 & 0.3 & 0.0 & 0.0 & 0.0 & 0.2 \\
\hline $1981-1990$ & 0.4 & 0.3 & 0.2 & 0.4 & 0.4 & 0.7 & 0.7 & 0.3 & 0.5 & 0.5 & 0.4 & 0.3 & 0.4 \\
\hline $1991-2000$ & 0.4 & 0.5 & 0.5 & 0.7 & 0.7 & 0.8 & 1.0 & 0.0 & 0.5 & -0.5 & 1.0 & 0.4 & 0.6 \\
\hline $2001-2008$ & 0.5 & 0.5 & 0.6 & 0.5 & 0.5 & 0.7 & 0.5 & 0.6 & 0.5 & 0.5 & 0.1 & 0.6 & 0.5 \\
\hline
\end{tabular}

in the last decade of the $20^{\text {th }}$ century, whereas the shortest summers were observed in the period 1961-1970.

3. The climate in Warsaw Ursynów over the long-term period of 1961-2012/13 was characterised by a substantial yearby-year variability of the dates and duration of the seasons. However, the average dates and lengths of thermal seasons, determined using the method of five-day rolling averages, proved to be similar to those established by means of other methods for stations situated in the same climatic region.
4. The approach based on five-day rolling averages posed the biggest methodological problems (as described in the Materials and method section) when applied to the determination of the duration of winter and early spring. The authors believe that the method can be applied to determine all seasons of the year; however, with regard to early winter, winter or early spring, when the variability of air temperature is the greatest, none of the available methods are capable of providing satisfactory results.

\section{References}

Degirmendžić, J \& Kożuchowski, K 2004, 'Zmiany termicznych pór roku w Łodzi w latach 1947-2003', Acta Geographica Lodziensia, vol. 89, pp. 59-71.

Franków, K 2008, 'Termiczne Pory Roku na Pomorzu Zachodnim w Stacji Geokologicznej Zintegrowanego Monitoringu Środowiska Przyrodniczego w Storkowie w latach 19872007', Badania Fizjograficzne nad Polską Zachodnią, vol. 59, issue 1, pp.77-88.

Gołaszewski, D, Majewski, G \& Przewoźniczuk, W 2007, 'Oddziaływanie budownictwa kubaturowego i sztucznych źródeł ciepła na intensywność miejskiej wyspy ciepła w
Warszawie', Acta Scientiarum Polonorum, seria Architectura, vol. 6, pp. 23-32.

Gumiński, R 1948, 'Próba wydzielenia dzielnic rolniczoklimatycznych w Polsce', Przegląd Meteorologiczny i Hydrologiczny, vol. 1. pp. 7-20.

Hess, M 1965, 'Piętra klimatyczne w Polskich Karpatach Zachodnich', Zeszyty Naukowe UJ, Prace Geograficzne, vol. 11.

Hess, M 1974, 'Klimat Krakowa', Folia Geogr., Seria Geogr.Phys., vol. 8, pp. 45-102.

Kossowska-Cezak, U 2005, 'Zmiany termicznych pór roku w 
Warszawie w okresie 1933-2004', Przegląd Geofizyczny, vol. 50, pp. 265-277.

Majewski, G, Odorowska, M \& Rozbicka, K 2012, 'Analiza warunków termicznych na stacji Ursynów-SGGW w Warszawie w latach 1970-2009', Woda-ŚrodowiskoObszary Wiejskie, vol. 12, no.2, pp. 171-184.

Majewski, G, Przewoźniczuk, W \& Kleniewska, M 2014, 'The effect of urban conurbation on the modification of human thermal perception as illustrated by the example of Warsaw (Poland)', Theoretical and Applied Climatology, vol. 116, pp. 147-154. DOI 10.1007/s00704-013-0939-4.

Makowiec, M 1983, 'Wyznaczanie termicznych pór roku', Przegląd Geofizyczny, vol. 28, no. 2, pp. 209-220.

Merecki, R 1915, 'Klimatologia ziem Polskich', Księgarnia Geberthera i Wolfa, Warszawa.

Nowosad, M \& Filipiuk, E 1998, 'Zmiany czasu trwania termicznych pór roku w Lublinie w latach 1951-1995', Acta Universitatis Lodziensis, Folia Geographlca Physica, vol. 3 , pp. 231-240.

Piotrowicz, K 2000, 'Zróżnicowanie termiczne pór roku w Krakowie', Prace Geograficzne, vol. 105, pp.111-124.

Piotrowicz, K 2002, 'Metody wyznaczania dat początku i końca termicznych zim na przykładzie krakowskiej serii pomiarów temperatury powietrza', Przegląd Geofizyczny, vol. 1-2, pp. 81-92.
Rozbicki, T, Łykowski, B \& Gołaszewski, D 2005, 'Wpływ budowy dzielnicy mieszkaniowej Ursynów na klimat lokalny', WodaŚrodowisko-Obszary Wiejskie, vol.5, no.14, pp. 261-273.

Romer, E 1938, 'Pogląd na klimat Polski', Czas. Geogr., vol. 16, pp. 193-224.

Romer, E 1949, 'Regiony klimatyczne Polski', Prace Wrocławskiego Towarzystwa Naukowego, vol. 16, Wrocław. Samborski, AS \& Bednarczuk, J 2009, 'Termiczne pory roku w okolicach Zamościa w latach 2001-2008', Acta Agrophysica, vol. 14, pp. 187-194.

Skowera, B \& Kopeć, B 2008, 'Okresy termiczne w Polsce południowo-wschodniej (1971-2000)', Acta Agrophysica', vol. 12, pp. 517-526.

Stopa, M 1968, 'Temperatura powietrza w Polce', Dokumentacja Geograficzna, vol. 2, Instytut Geografii PAN, Warszawa, pp. 210.

Szyga-Pluta, K 2011, 'Termiczne pory roku w Poznaniu w latach 2001-2008', Przegląd Geograficzny, vol. 83, no.1, pp. 109119.

Trepińska, J (ed.) 1997, 'Wahania klimatu w Krakowie (17921995)', Instytut Geografii UJ, Kraków.

Wiszniewski, W 1960, 'Kilka uwag o meteorologicznych porach roku w Polsce w świetle średnich wieloletnich wartości temperatur', Przegląd Geofizyczny, vol. 5, no.1. pp. 31-39. 